\title{
REVIEW \\ Jeremy Brown \\ New Heavens and a New Earth: The Jewish Reception of Copernican Thought
}

(New York: Oxford University Press, 2013), hardcover, xviii + 394 pp.

Rachel S. A. Pear, Bar Ilan University / University of Haifa

During the last half-century, writings on Judaism and science, especially those by Orthodox Jews with medical training, largely dealt with Jewish legal (halakhic) issues. As interesting as halakhic definitions of brain death and assisted fertility technologies may be, they are somewhat narrow in their scope compared to the broader issues that emerge from studying the interaction of science and religion, especially topics that are most fruitful for interfaith dialogue. Therefore Jeremy Brown's book on Jews' reception of Copernican thought is exactly the refreshing and broadening new perspective that discourse regarding Judaism and science needs. Taking on the ambitious project of tracing Jewish responses to Copernican thought from the $16^{\text {th }}$ century to the present in various geographical contexts, Brown, a professor of medicine at George Washington University, looks at those who were sympathetic to and also those who were critical of Copernicus' project. He emphasizes the diversity in responses, arguing that there has been no smooth or linear path to the Jewish acceptance of a heliocentric world-view.

This conclusion undermines the myth that, unlike Christians, Jews have never resisted the findings of scientific research. In fact, in a recent debate in the Knesset on the teaching of evolution in the Israeli school system, the committee head, ultraorthodox parliamentarian Moshe Gafni stopped another speaker whose testimony mentioned Galileo in order to inter- 
ject that traditional Jews "never had a problem with [the heliocentric view]." Brown's book clearly proves this statement wrong, along with other generalizations about the Jewish reception of Copernicus. Instead, he raises the more interesting questions of when and why some religious traditionalists fought new scientific findings while others embraced them. Indeed, the recent Knesset incident is an illustration of one of the main tenets in disciplines related to the history of science: because modern science is made up of the scientific theories that have won the day, many also assume these theories had smooth paths to victory over other views, both within the scientific community as well as in terms of their reception among the rational public, underestimating the multifaceted controversies they provoked along the way. This "myth-busting" component of Brown's work of scholarship will be of interest not only to academics in fields such as Jewish Studies and the History of Science, but to many non-academics as well. Perhaps it should even be distributed in certain Knesset subcommittees!

Brown, following historian David Livingstone and other scholars of the history of science, insists that historians "pluralize, localize, politicize," and look for "hybridization" in explaining interactions between science and religion (p. 276). He rejects broad abstractions and generalizations about religious traditions and says that scholars must attend closely to social and cultural context. For example, Brown emphasizes that some of the first Jewish scientists to consider the heliocentric view in a positive light, such as David Gans (1541-1613) and Joseph Delmedigo (1591-1655), were individuals who had the opportunity to learn directly from the greatest astronomers of their time, such as Tycho Brahe and Galileo, and that personal relationships had a significant influence on their views. Similarly, Brown argues that at least one of the individuals who avoided confronting the issue of the heliocentric view in his writings on astronomy, David Mendola in the 18th century, may have done so because he was influenced by bans on books on even less controversial subjects that he had witnessed. Of course, Brown is not the first author to address the issue of Jews' 
reception of scientific knowledge. Historians such as David Ruderman and Noah Efron, among many others, are mentioned by Brown, and they certainly paved the way for this book with their work. Also it is relevant to note that while many may be quite satisfied with Brown's emphasis on pluralizing and localizing, others may be bothered that Brown stops short of suggesting more generalized patterns that emerge from the numerous Jewish views he describes, which would in turn allow for comparisons with patterns regarding Christian views, for instance.

As may often be the case, the book's strengths could also be considered its weaknesses. For experts in particular fields, it may be frustrating that Brown attempts to cover so much ground and therefore cannot contextualize all of the authors surveyed to the same extent. However, despite its drawbacks, I believe Brown's decision to cover more ground is the right one, because he thereby attempts to address a significant historical question in its entirety. Perhaps the decision to trace the reception of a single scientific idea through an extended period of time as opposed to analyzing Jewish engagement with science more generally within a particular historical or geographic context may give this book popular appeal, outside an academic context. Not every point Brown makes is as clear as it could be, and some of the material presented could use further analysis. However, what is most important about this thoroughly researched and well-executed book is that it begins a generative conversation. Those interested in the interaction of science and religion, as well as interfaith dialogue, will be grateful. 